\title{
REACTIVE POWER CONTROL OF THREE-PHASE MODULE INTEGRATED PV MICRO-INVERTER BASED ON BOOST CONVERTER
}

\author{
${ }^{*}$ Farah T. Noori ${ }^{1}$
}

Turki K. Hassn ${ }^{1}$

1) Electrical Engineering Department, College of Engineering, Mustansiriyah University, Baghdad, Iraq

\begin{abstract}
In recent years, photovoltaic power generation has become a creative technology. This technology uses solar energy to overcome the energy shortages in modern power systems because of increasing environmental problems in traditional power generation systems. It has irreplaceable benefits like pollution reduction and has increasingly been turned into a new path for distributing power generation applications. In traditional PV system design to produced enough DC-bus voltage from PV panels, several PV modules are connected in series connection. However, when certain modules are partially shadowed, the overall power generation of the PV panels often falls significantly, reducing its essential current generation and preventing the output current from reaching its maximum value within that panels. An AC modules strategy was suggested in this paper to solve this drawback. The PV system with an interleaved DC-DC boost converter and maximum power point tracker (MPPT) for each boost converter is used in the DC-DC converter stage. The perturbation and observation (P\&O) algorithm is applied to extract sun power. In this paper, a three-phase microinverter voltage source inverter type (VSI) of $1000 \mathrm{~W}$ is designed and simulated. By controlling the direct and quadrature components of inverter output currents, the active and reactive power can be injected into the grid. The system is simulated using MATLAB software and the simulation results show the validity of the suggested Micro-inverter system.
\end{abstract}

Keywords: Photovoltaic; Interleaved boost converter; Micro-inverter; Grid-connected

\section{Introduction}

Renewable energies particularly solar, are an interesting and growing alternative electricity generation source in recent years. Solar power is abundant, renewable and pollution-free. It is most commonly available in the midst of increased natural energy interest. Several types of inverter circuits and the corresponding control systems have been studied for PV systems.

The new Global Trends in Renewable Energy 2020 report shows that, except for large hydropower plants, renewable energy capacity increased by 184 gigawatts $(\mathrm{GW})$ in 2019 . This reflects a $20 \mathrm{GW}$ or $12 \%$ per cent improvement over 2018 's latest capabilities [1]. Resources of electrical energy can primarily be divided into three sets: nuclearpowered, fossil and renewable energy resource. Renewable energy sources will be one of the most widely-researched among others [2] [3].

The photovoltaic voltage should be boosted by used several numbers of PV panel to achieve the required voltage and it can be optimized between the PV module and inverter. When a PV system provided with a DC-DC converter or a transformer for amplifying voltage, then fewer PV modules in sequence are needed. MPPT added to each string can be separated. This improves performance overall in comparison with the centralized inverter and lowers price due to mass production. The AC module strategy has been suggested to overcome this

*Corresponding Author: farahthamer3@gmail.com 
drawback. AC module system, with ranging of low power levels of micro-inverter is used in this paper, due to its many advantages including: (1) Improved the energy harvesting (2) Improved efficiency of the system (3) lower cost of installation (4) Operation "Plug-NPlay" (5) Increased modularity and flexibility 6) Reduction in DC-Link capacitance [4]. AC module type removes the contrast between PV modules if only one PV module is available and it allows for optimal adjustment among the PV module and inverter and thus using individual MPPT. The input power generated by the PV modules $(\mathrm{PPV})$ is controlled to be a constant and work at (MPPT) by using the P\&O algorithm method because it's simplest and basic in structure [5]. A modular structure includes the option of a simple system structure and the capability of an increase in size. There is also the challenge of unit cost reduction and increasing efficiency of conversion of the PV micro-inverter systems, which persons can use without knowledge of electrical installation, with a " plug \& play " option, improved efficiency and extension, superb system redundancy and no DC coupling and safety problem [6]. In addition to these techniques, a review of the literature on the basis of reactive power control and the effective voltage regulation problem were presented in [7]-[10].

This paper introduces the design of a low power rated photovoltaic micro-inverter. On the one hand, can be used for home independent power supply systems. On the other hand, can supply the grid with electricity [11].

Special requirements for a high-quality electrical power system are needed in this electric network connection system. In this paper, the authors focus on two main problems such as control of DC-link voltage and the ability to inject a reactive power control. Many research study micro-inverters which work in the state of a unity power factor and cannot provide reactive power production, thereby failing to satisfy some electric power regulations [12], [13]. This paper suggested an enhanced photovoltaic MPPT control algorithm (P\&O) under fast-changing solar radiation. The threephase micro-inverter of $1000 \mathrm{~W}$ is designed, it can inject active and reactive power into the grid by control the direct and quadrature current components. The feasibility of the scheme is shown by the simulation of the MATLAB software. This paper is organized as follows: Section 2 introduces the configuration of microinverter system; Section 3 presents the operating principles and the control for tracking MPP and the control scheme of the micro-inverter; Section 4 shows the simulation to verify the presented methods; Section 5 shows the final conclusion of this paper.

\section{Circuit Configuration}

Figure 1, shows configuration of circuit of PV inverter connected to the three-phase utility grid. It consists of PV arrays, DC-DC boost converter for each panel, DC-link capacitor and DC-AC converter. The MPPT operation is controlled with the boost converter. An active and a reactive power transfer to the utility grid by three-phase micro-inverter [14].

The system circuit is divided in two stages. The first stage is responsible to increase the input voltage and the MPPT closed loop.

The location of the boost converter would enhance the overall photovoltaic system installation, permitting various controls of system by maximum power point monitoring using the (P\&O) algorithm method. Many researchers study boost converter in their research in photovoltaic system such as [15] [16]. The second stage is DC-AC conversion stage and three-phase filter. 


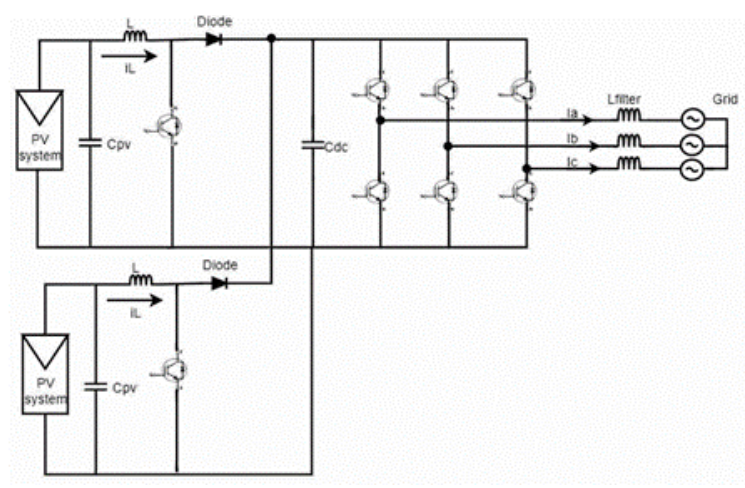

Figure 1. Three-phase grid connected circuit configuration of micro-inverter system.

\section{Photovoltaic Power System}

Figure 2, shows the proposed micro-inverter circuit of PV inverter attached to the three-phase utility grid. The system is consist of a PV panel, interleaved DC-DC boost converter, DC-AC converter (VSI) and filter. The P\&O MPPT algorithm controlled with the boost converter stage. An active and a reactive power transfer to the utility grid by three-phase micro-inverter [17].

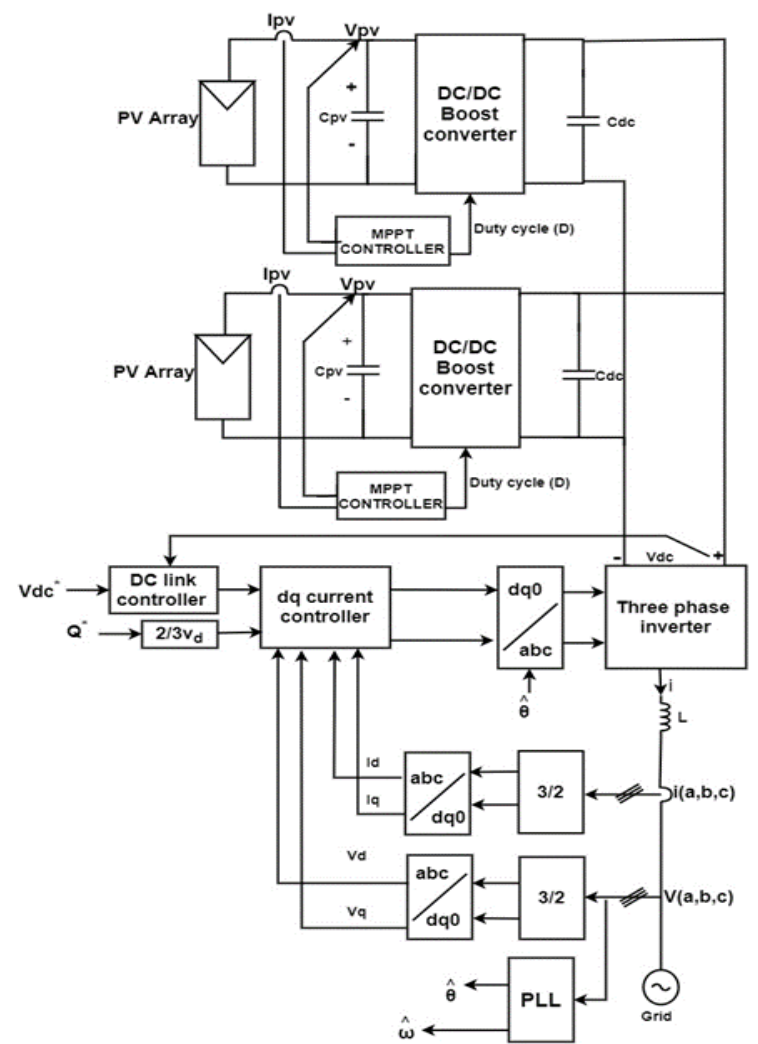

Figure 2. The proposed micro-inverter with control scheme

\subsection{MPPT Algorithm}

The maximum power point tracking (MPPT) algorithm founded by $(\mathrm{P} \& \mathrm{O})$ used in this design due to its very simple and easy to implement.

The $\mathrm{P} \& \mathrm{O}$ algorithm compares the previously given power with power after disturbances by varying periodically the panel voltage by a small increment step to reduce the MPP oscillation at the desired zone [18], [19].

This method tests the PV power to review the running effective area. Depending on this area, a boost converter duty cycle (D) is decreased or increased in this away such this system works near the maximum point of power. Since the method compares PV power output, it's easy to implement. Due to their simplicity and inclusion of few measured parameters, this algorithm has a wide use in commercial systems. Figure 3, shows the maximum power point tracking (MPPT) method, where MPP is the maximum power point, $\mathrm{P}_{\mathrm{pv}}$ is the power of photovoltaic panel, while $\mathrm{V}$ is the voltage of photovoltaic panel, $\Delta \mathrm{P}$ is the difference between previous and next photovoltaic power and $\Delta \mathrm{V}$ is the difference between previous and next photovoltaic voltage.

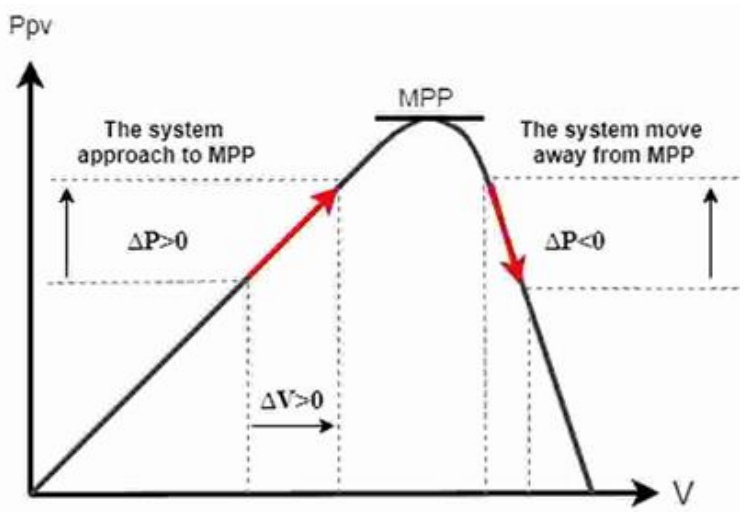

Figure 3. The MPPT $(\mathrm{P} \& \mathrm{O})$ algorithm.

\subsection{Control Strategy}

The system circuit is divided into two stages. The first stage is responsible to increase the input voltage (DC-DC conversion stage) with 
closed loop the MPP tracker. Interleaved DCDC boost converter with phase shift $180^{\circ}$ is suggested in this paper to increase the power produced by PV panels. The location of the boost converter would enhance the overall photovoltaic system installation, permitting various controls of a system by MPP tracker of the (P\&O) algorithm method [15], [16].

The control diagram in MATLAB program is shown in figure 4 . The figure obtained that the controller of output currents is provided with two control loops including active power and reactive power control. For synchronization between grid and PV voltage, it requires grid parameters (voltage and current) and output voltage of DC boost converter. The output of an inverter control circuit is required to generate PWM signals. The DC-link voltage is determined and compared with required value of $420 \mathrm{~V}$ (reference voltage). The direct current component $I_{d}$ is the active power component of the output currents that is compared with the output of the voltage PI control is $\mathrm{I}_{d}{ }^{*}$. The reactive current $\mathrm{I}_{\mathrm{q}}$ is regulated using PIcontroller to determine the required reactive power (Q) [14].

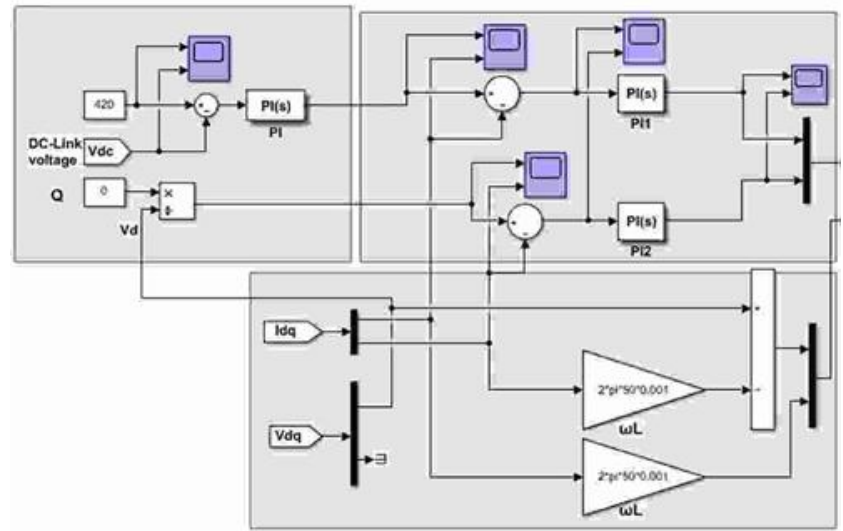

Figure 4. The control diagram of DC voltage regulation and reactive power control.

The active power $(\mathrm{P})$ and reactive power $(\mathrm{Q})$ are measured with Equation 1 in the stationary reference frame. The $\mathrm{v}_{\mathrm{q}}$ is close to zero while the rotating reference frame $v_{d}$ component is match with the voltage of grid in the rotational reference frames then $\mathrm{P}$ and $\mathrm{Q}$ can be obtained by Equation (2).

$P=\frac{3}{2}(v \alpha i \alpha+v \beta i \beta), Q=\frac{3}{2}(v \alpha i \beta-v \beta i \alpha)$
$P=\frac{3}{2}($ vdid + vqiq $)=\frac{3}{2}$ vdid, $Q=\frac{3}{2}$ vd iq

The PI controller parameters of the DC-link voltage control loop is $K_{p}=0.09$ and $K_{i}=20$. The PI-controller parameters of the active current component are $\mathrm{K}_{\mathrm{p}}=50$ and $\mathrm{K}_{\mathrm{i}}=16.6667$. The PIcontroller parameters of reactive power component are $\mathrm{K}_{\mathrm{p}}=0.5$ and $\mathrm{K}_{\mathrm{i}}=1666.6667$ all values are chosen to give good system performance (Small overshoot and steady-state error).

PLL control is necessary for the utility system to match the interconnected utilities with the output voltage of the inverter. The three-phase voltage of the grid is known and transform to the quantity of the space vector as shown in figure 5, [20] [21].

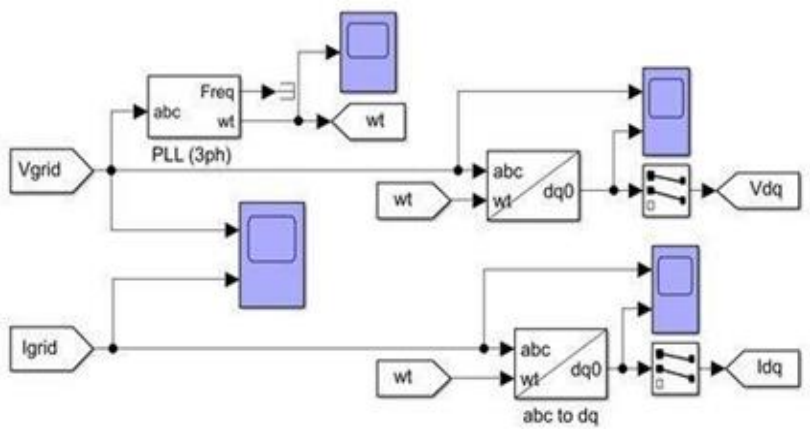

Figure 5. Phase locked loop controller.

The parameters of the micro-inverter PV system using in a simulation are obtained in table 1.

Table 1. Specifications of the three-phase Micro-Inverter

\begin{tabular}{lcc}
\hline Parameter & Value & Unit \\
Boost output DC voltage & 420 & $\mathrm{~V}$ \\
Grid voltage (line-line) & 220 & $\mathrm{~V}$ \\
L $_{\text {boost }}$ & 1.5 & $\mathrm{mH}$ \\
$\mathrm{L}_{\mathrm{f}}$ & 3 & $\mathrm{mH}$
\end{tabular}


Switching frequency $\left(f_{s}\right)$

$50 \quad \mathrm{kHz}$

Rated power

1000

W

Output frequency

50

$\mathrm{Hz}$

The PV panel specification is shown in Table 2.

Table 2. PV panel specification.

\begin{tabular}{lcc}
\hline \multicolumn{1}{c}{ Parameter } & Value & Unit \\
\hline Maximum power $\left(\mathrm{P}_{\max }\right)$ & 250 & $\mathrm{~W}$ \\
Current at maximum power point & 6.96 & $\mathrm{~A}$ \\
$\left(\mathrm{I}_{\max }\right)$ & & \\
Voltage at maximum power & 36 & $\mathrm{~V}$ \\
point $\left(\mathrm{V}_{\text {max }}\right)$ & & \\
Short circuit current $\left(\mathrm{I}_{\mathrm{sc}}\right)$ & 8 & $\mathrm{~A}$ \\
Open circuit voltage $\left(\mathrm{V}_{\mathrm{oc}}\right)$ & 40.7 & $\mathrm{~V}$ \\
Shunt resistance $\left(\mathrm{R}_{\mathrm{sh}}\right)$ & 1000 & $\Omega$ \\
Series resistance $\left(\mathrm{R}_{\mathrm{se}}\right)$ & 0.008 & $\Omega$ \\
Temperature coefficient of $\mathrm{V}_{\mathrm{oc}}$ & -0.36099 & $\% / \mathrm{deg} . \mathrm{C}$ \\
Temperature coefficient of $\mathrm{I}_{\mathrm{sc}}$ & 0.102 & $\% / \mathrm{deg} . \mathrm{C}$ \\
Diode ideality factor & 1.2 & - \\
\hline
\end{tabular}

\section{Simulation Results}

The MATLAB software program is used in this simulation. PV panel operated at a standard solar intensity of $\left(1000 \mathrm{~W} / \mathrm{m}^{2}\right)$ and temperature $\left(25^{\circ} \mathrm{C}\right)$.

The PV panel is used in simulation with specifications shown in Table 2. Figure 6, shows the $\mathrm{PV}$ output voltage (DC-voltage) $\mathrm{V}_{\text {in }}=$ $72 \mathrm{~V}$ with small voltage ripple $\mathrm{V}_{\text {ripple }}=0.621 \mathrm{~V}$.

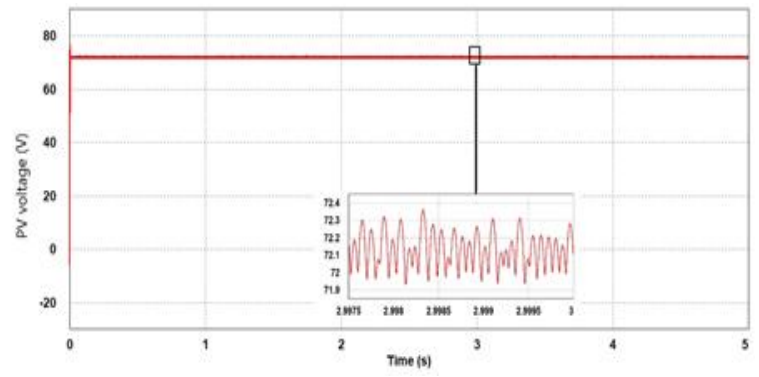

Figure 6. PV array output voltage.
Figure 7, shows the PV output current, whose value of $\mathrm{I}_{\mathrm{in}}=6.7 \mathrm{~A}$ with a small ripple value $\mathrm{I}_{\text {ripple }}=0.12 \mathrm{~A}$.

The output power of each PV with 500W for irradiation of $1000 \mathrm{~W} / \mathrm{m}^{2}$ and temperature of $\mathrm{T}=$ $25^{\circ} \mathrm{C}$ array is shown in figure 8 .

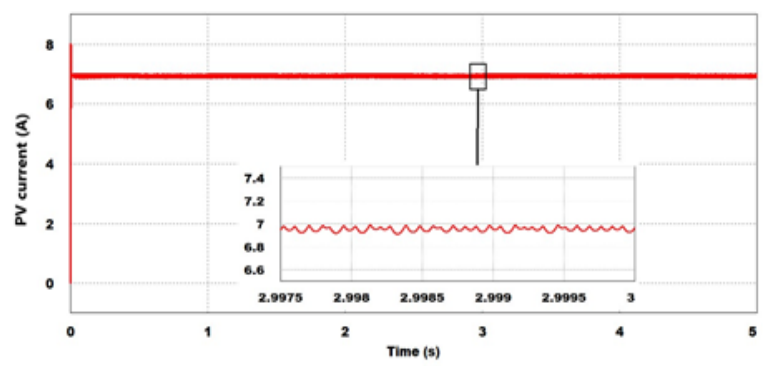

Figure 7. PV array output current.

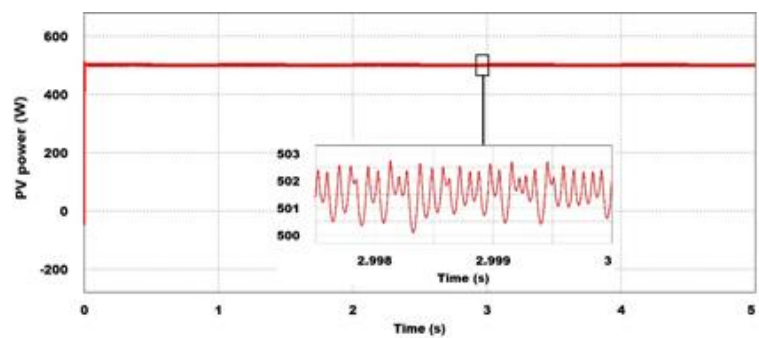

Figure 8. PV array output power.

Figure 9, shows the drive signal waveform of the IGBT switch of each boost converter. To ensure the PV system at its maximum power point, the switching cycle varies accordingly. The value of the duty cycle to give maximum power is 0.82857 .

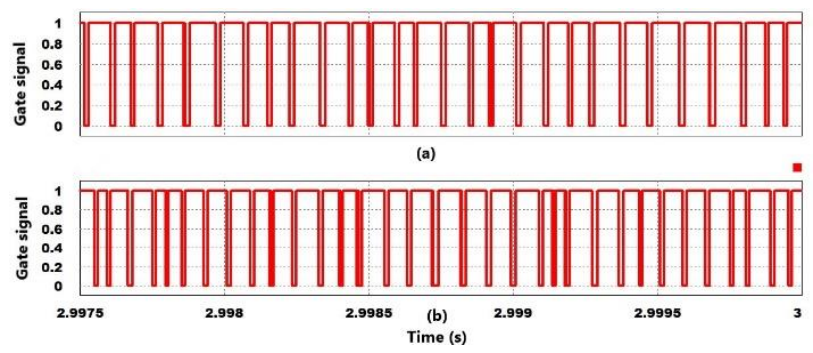

Figure 9. Gate pulses of DC-DC converter (a) for converter1 (b) for converter2.

Figure 10, shows the current flowing in each boost inductor of a DC-DC boost converter. The value of peak-to-peak current ripple is $4.1776 \mathrm{~V}$. 


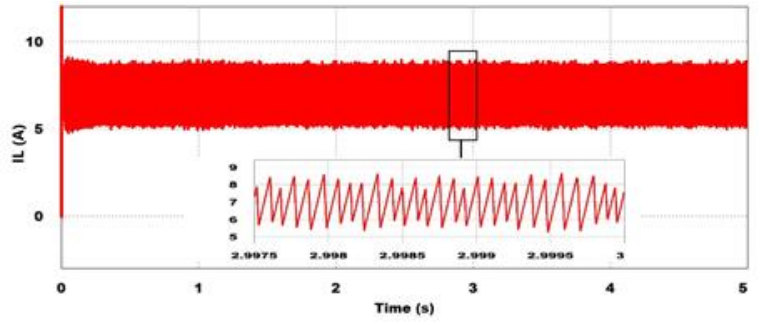

Figure 10. Boost inductor current.

The voltage source inverter (VSI) is associated with the following waveforms. The voltage source inverter input is DC voltage shown in figure 11 . The DC-DC boost converter regulates its output voltage to match the reference value (420). $\mathrm{V}_{\mathrm{ab}}$ is the inverter output line to line voltage after a grid connection is seen in figure 12.

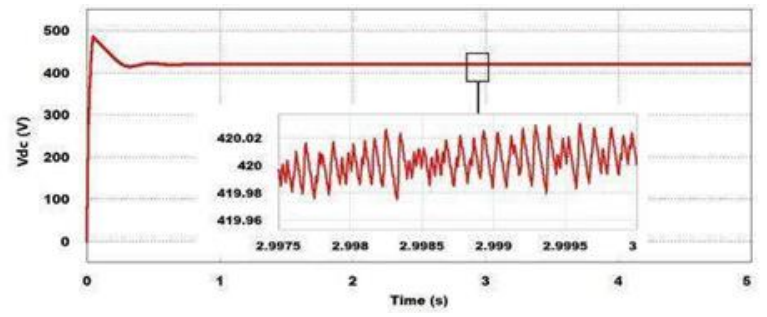

Figure 11. Input DC voltage of three-phase voltage source inverter VSI.

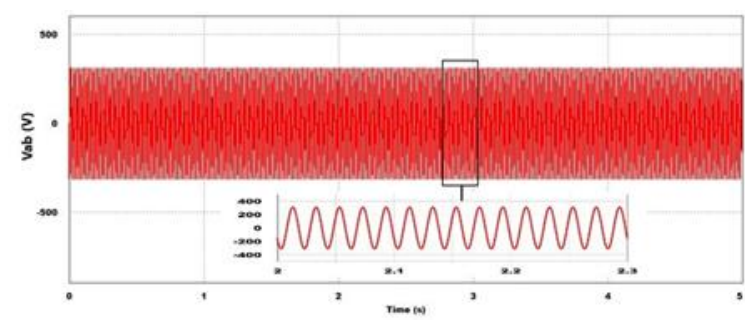

Figure 12. Inverter output line voltage $\mathrm{V}_{\mathrm{ab}}$ after the grid connection.

The active power and reactive power injected into the grid are proportional to the direct current component $\left(\mathrm{I}_{\mathrm{d}}\right)$ and quadrature current component $\left(\mathrm{I}_{\mathrm{q}}\right)$ respectively. Figure 13, shows the direct component response that follows the output of PI-controller of DC voltage loop with a steady-state value of 3.66A, the injected active power is 1000W. Figure 14, shows the quadrature current component which is controlled to zero using a PI controller, this means that no reactive power injected into the grid.

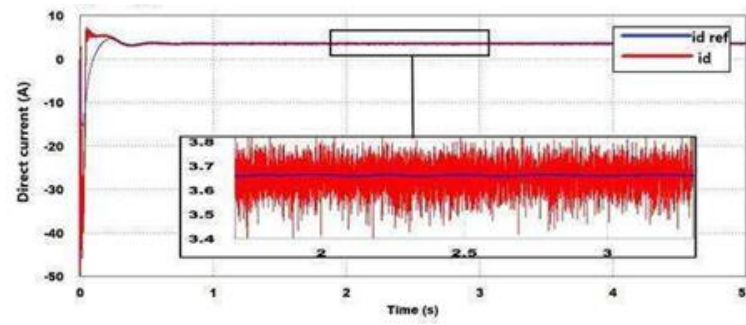

Figure 13. Direct current component $I_{d}$.

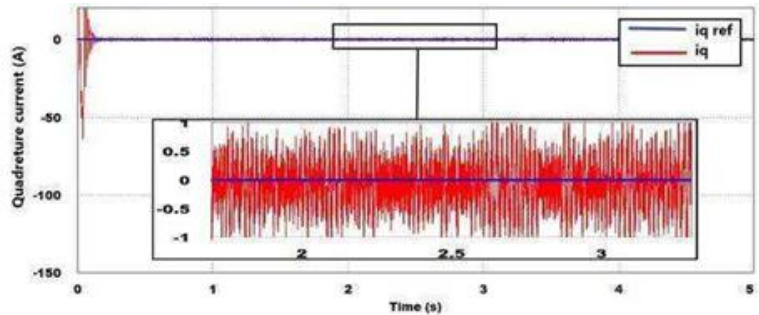

Figure 14. Quadratic current component $I_{q}$.

\subsection{Micro-Inverter Waveforms in Full Power Condition}

Figure 15, shows the micro-inverter waveforms that run in full power condition. In this status, each PV array light intensity was defined set at $(1000,1000) \mathrm{W} / \mathrm{m}^{2}$ respectively, and the output power of the PV array was estimated were PPV1 $=500 \mathrm{~W}, \mathrm{P}_{\mathrm{PV} 2}=500 \mathrm{~W}$. The desired features are achievable in PV systems, such as near sinusoidal output currents, unity power factor and the separate MPPT. THD of output current is $5.3 \%$.

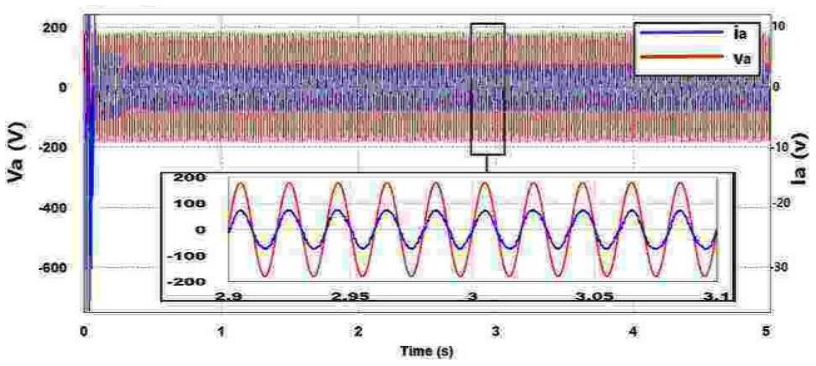

(a) 


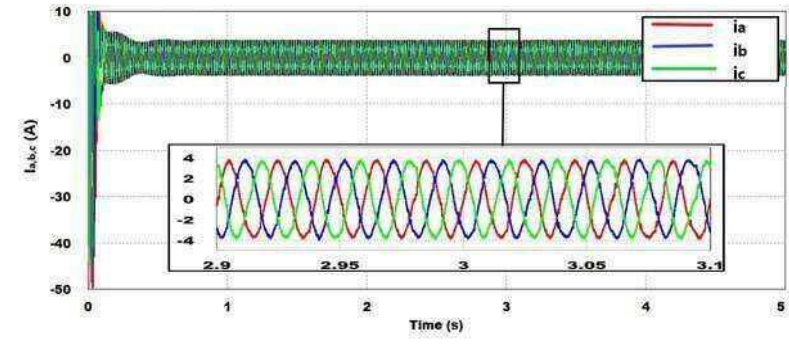

(b)

Figure 15. Waveforms of the micro-inverter working in full-power condition. (a)Output phase voltage and output phase current (b) three-phase output currents.

\subsection{PV panels under different irradiation}

Figure 16, represents the micro-inverter waveforms operating with a half power by taking the PV panel under lower irradiation. In this scenario, it was defined that the light intensity of each PV arrays set at (500) W/m², and the output powers of photovoltaic array were $\mathrm{P}_{\mathrm{PV} 1}=250 \mathrm{~W}$, and $\mathrm{P}_{\mathrm{PV} 2}=250 \mathrm{~W}$ respectively. $\mathrm{I}_{\mathrm{d}}=1.85 \mathrm{~A}$ and the $\mathrm{I}_{\mathrm{q}}$ was set as zero. The waveforms appear in the figure, including the output phase voltage $\mathrm{v}_{\mathrm{a}}$ with phase current $i_{a}$ and the three-phase output currents $i_{a}$, $i_{b}$ and $i_{c}$. As is apparent from the figure, the three-phase output currents and the microinverter output power is about $500 \mathrm{~W}$, indicating that every boost converter is controlled for tracking its MPP effectively independently from each other by using the P\&O method. THD of output current is $11.7 \%$ and in phase with the grid voltage.

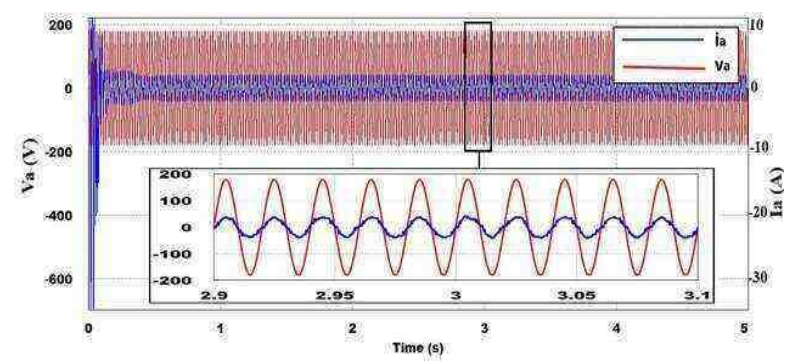

(a)

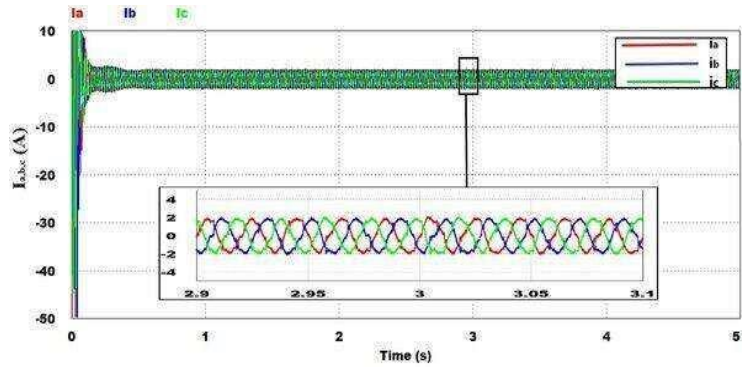

(b)

Figure 16. Micro-inverter simulated waveforms with a power of 500W (a) output phase voltage and output phase current (b) three-phase output current.

Figure 17, shows the PV current and PV voltage of the PV arrays at half power. Figure 18, shows the DC-Link voltage at half power. Figure 19, shows the $I_{d}=1.85 A$ and $I_{q}=0$ at half power.

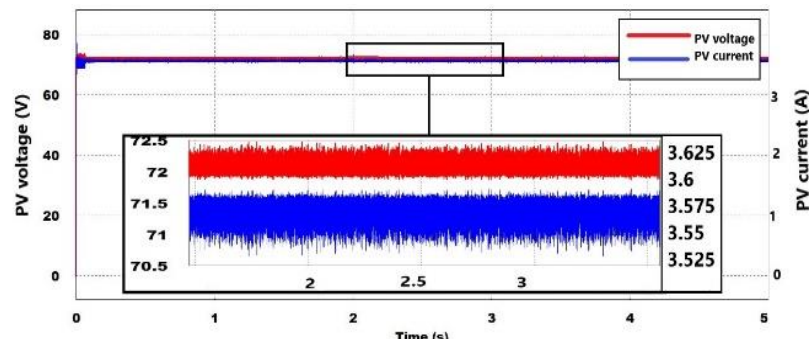

Figure 17. PV current and PV voltage at half power.

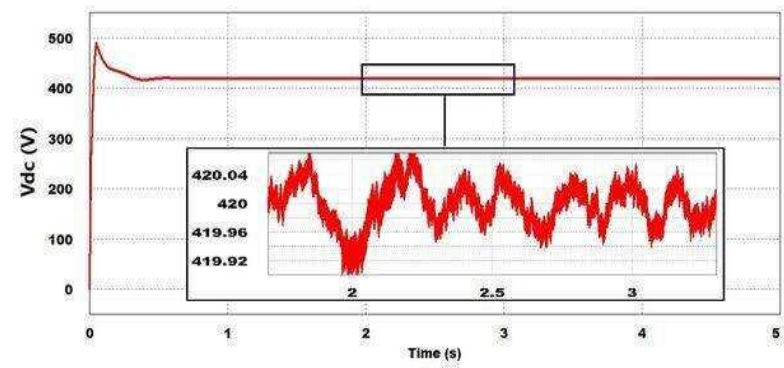

Figure 18. DC-link voltage at half power.

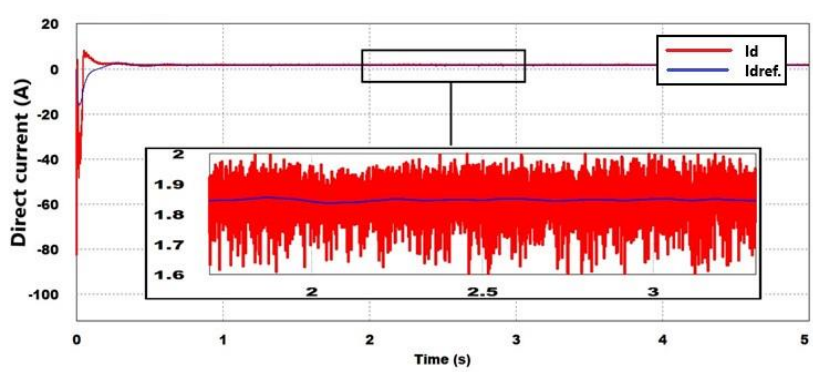

(a) 


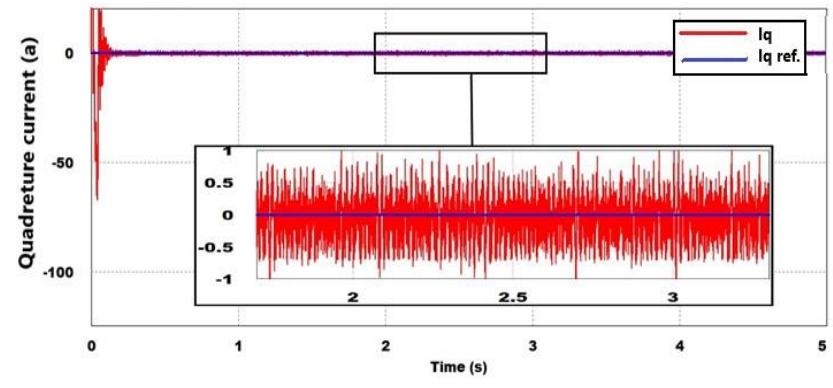

(b)

Figure 19. (a) $I_{d}$ and reference of $I_{d}$ at half power (b) $I_{q}$ and reference of $I_{q}$ at half power.

\subsection{Operation at different reactive power values}

The micro-inverter works under full-power condition $(1000 \mathrm{~W}), \mathrm{I}_{\mathrm{d}}=3.7 \mathrm{~A}$ and $\mathrm{I}_{\mathrm{q}}=0.995 \mathrm{~A}$ at output reactive power (268Var). Figure 20 (a), shows the voltage of phase a with the current of phase a. Figure 20 (b), shows the three-phase output currents. The displacement angle of the inverter output current is $15^{\circ}$ related to the reactive power injected into the grid. THD of output current is $6.477 \%$.

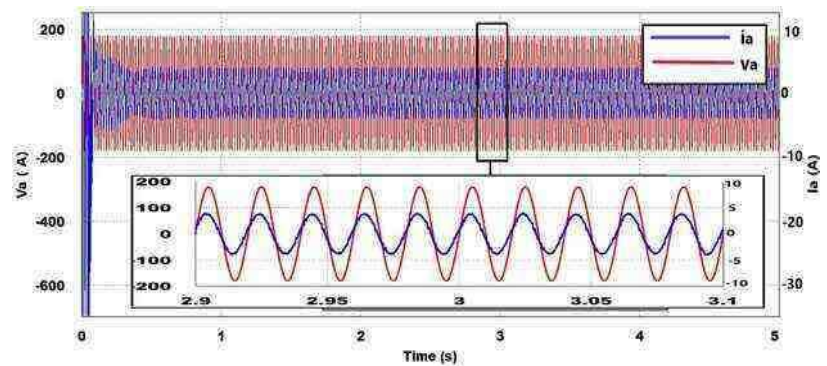

(a)

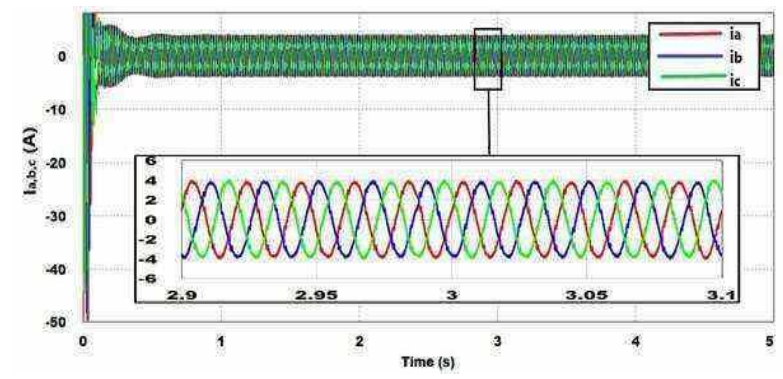

(b)

Figure 20. Micro-inverter waveforms with output reactive power of $268 \mathrm{~V}$ ar and phase displacement angle $15^{\circ}$ (a) output phase voltage and output phase current (b) three-phase output currents.
Figure 21, shows the PV current and PV voltage of the PV array at 268Var output reactive power and phase displacement angle $15^{\circ}$.

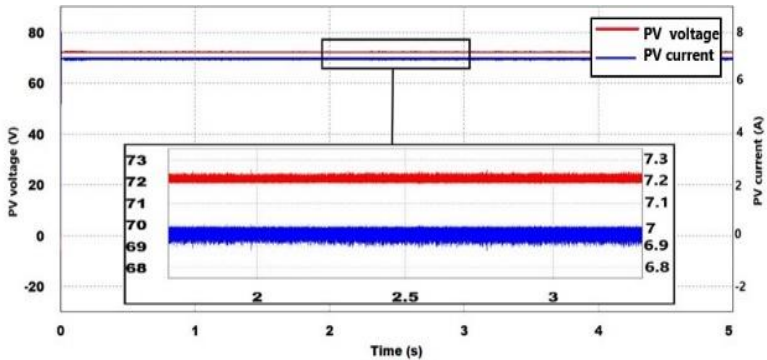

Figure 21. PV current and PV voltage at 268Var output reactive power and phase displacement angle $15^{\circ}$.

Figure 22, shows the DC-Link voltage at 268Var output reactive power and phase displacement angle $15^{\circ}$. Figure 23 , shows the $\mathrm{I}_{\mathrm{d}}=\mathrm{Id}=3.7 \mathrm{~A}$ and $\mathrm{I}_{\mathrm{q}}=0.995 \mathrm{~A}$ at $268 \mathrm{Var}$ output reactive power and phase displacement angle $15^{\circ}$.

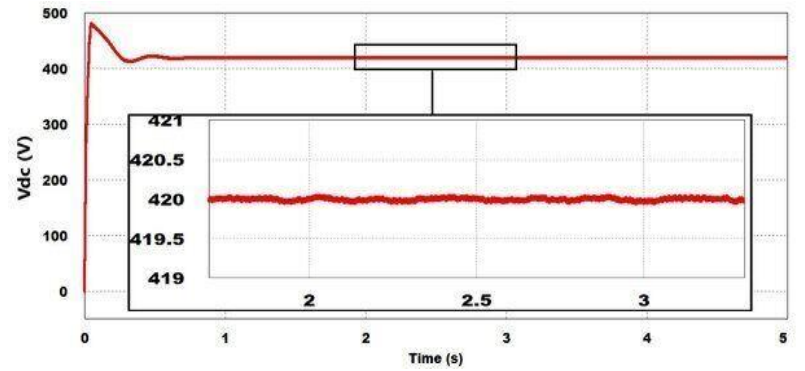

Figure 22. DC-link voltage at 268Var output reactive power and phase displacement angle $15^{\circ}$.

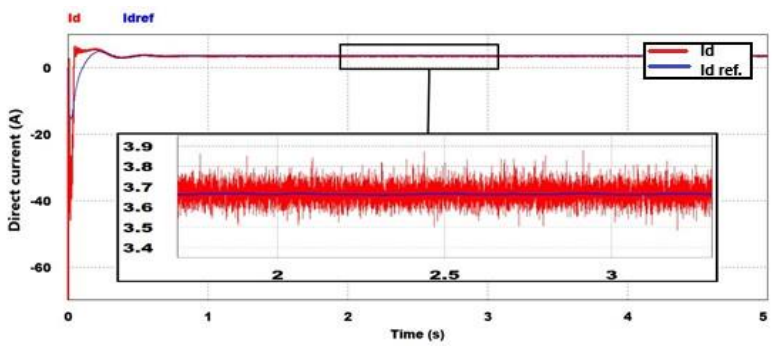

(a) 


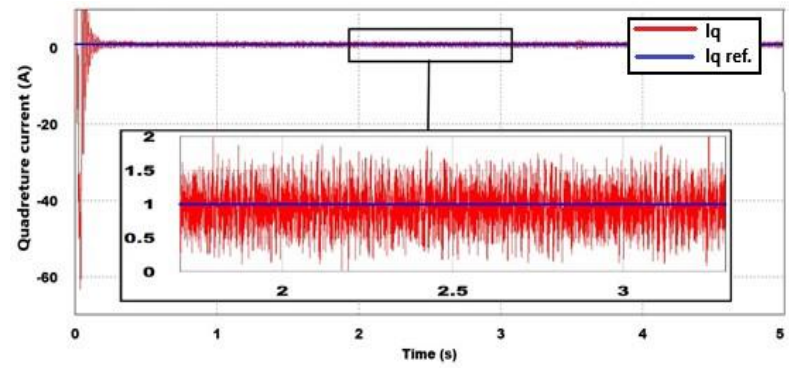

(b)

Figure 23. (a) $I_{d}$ and reference of $I_{d}$ at 268 Var output reactive power and phase displacement angle $15^{\circ}$ (b) $\mathrm{I}_{q}$ at 268Var output reactive power and phase displacement angle $15^{\circ}$.

Where the micro-inverter also runs under fullpower condition $(1000 \mathrm{~W}), \mathrm{I}_{\mathrm{d}}=3.67 \mathrm{~A}$ and $\mathrm{I}_{\mathrm{q}}=$ $2.142 \mathrm{~A}$ at output reactive power (577Var) as shown in figure 24. The displacement angle of the inverter output current is $30^{\circ}$. THD of output current is $6.9 \%$.

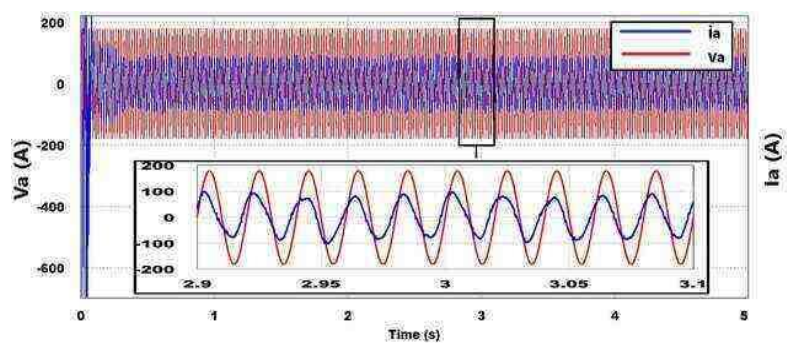

(a)

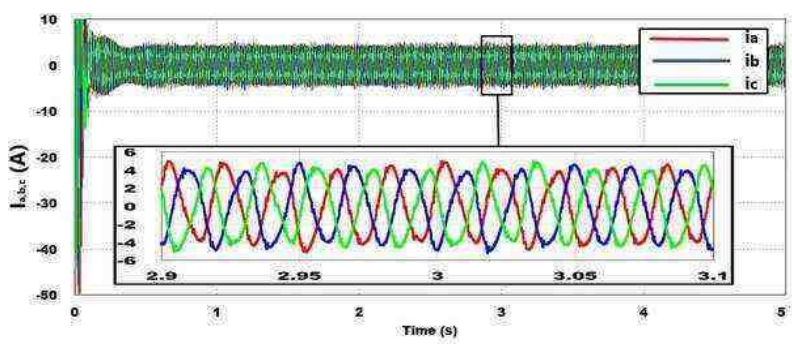

(b)

Figure 24. Micro-inverter waveforms with output reactive power of 577Var and phase displacement angle $30^{\circ}$ (a) output phase voltage and output phase current (b) three-phase output currents.

Figure 25, shows the PV current, PV voltage of PV array at 577Var output reactive power and phase displacement angle $30^{\circ}$.

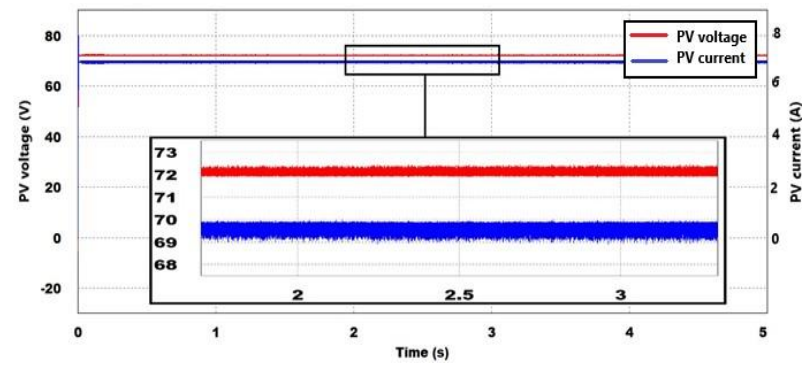

Figure 25. PV current and PV voltage at 577Var output reactive power and phase displacement angle $30^{\circ}$.

Figure 26, shows the DC-Link voltage at 577 Var output reactive power and phase displacement angle $30^{\circ}$. Figure $27, \mathrm{I}_{\mathrm{d}}=3.67 \mathrm{~A}$ and $\mathrm{I}_{\mathrm{q}}=2.142 \mathrm{~A}$ at $577 \mathrm{Var}$ output reactive power and phase displacement angle $30^{\circ}$.

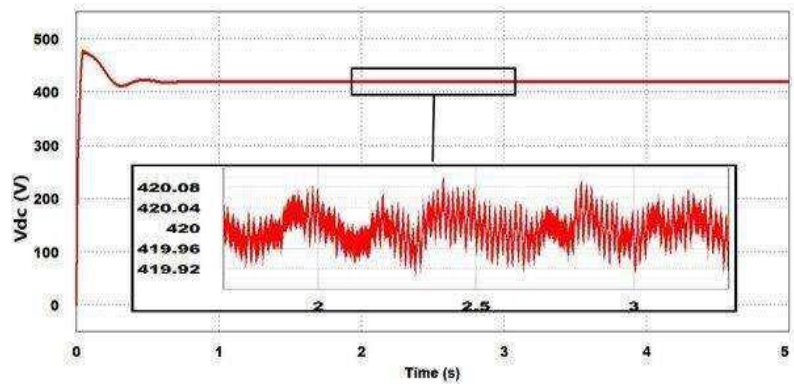

Figure 26. DC-link voltage at 577Var output reactive power and phase displacement angle $30^{\circ}$.

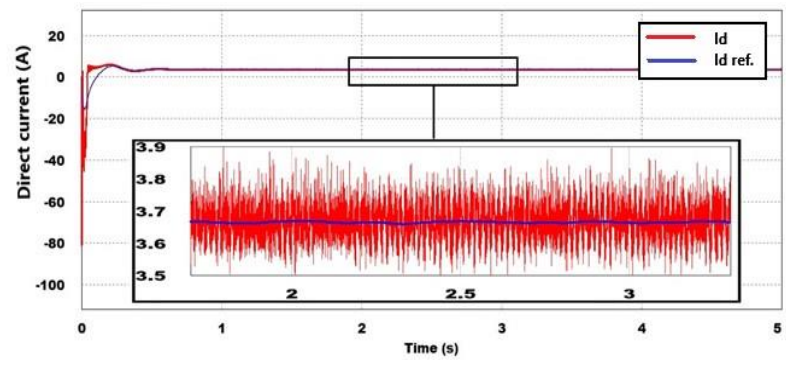

(a)

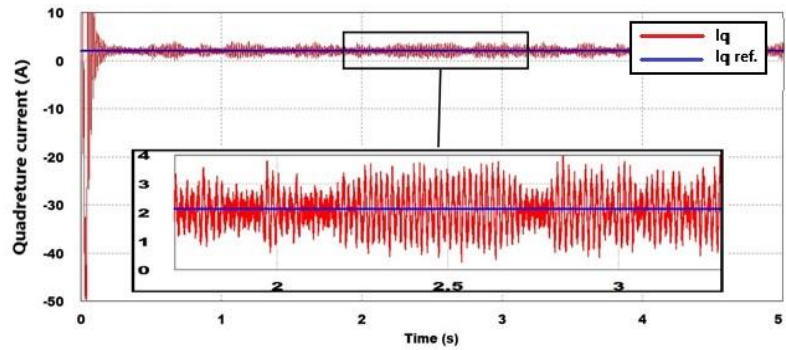

(b)

Figure 27. (a) $I_{d}$ and reference $I_{d}$ at 577Var output reactive power and phase displacement angle $30^{\circ}$ (b) $\mathrm{I}_{\mathrm{q}}$ and reference of $I_{q}$ at $577 \mathrm{Var}$ output reactive power and phase displacement angle $30^{\circ}$. 
Figure 28 (a) shows voltage and current of phase a, Figure 28 (b) shows output three-phase currents when The micro-inverter works under full-power condition (1000 W), Id =3.66 A and $I_{q}=-0.994 A$ at output reactive power $(-268$ Var) and the displacement angle of the inverter output current is $-15^{\circ}$ with THD of output current is $7.23 \%$.

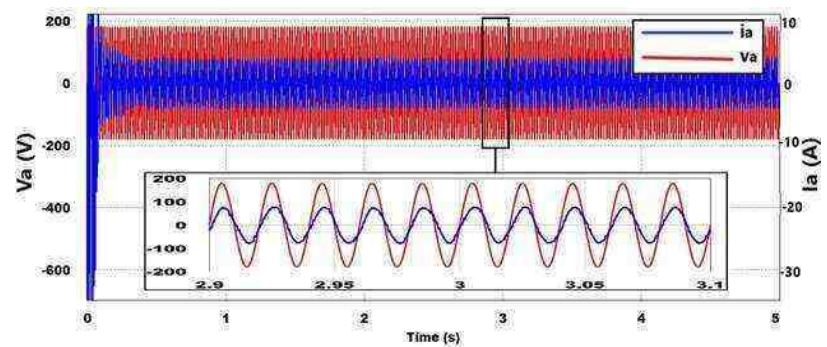

(a)

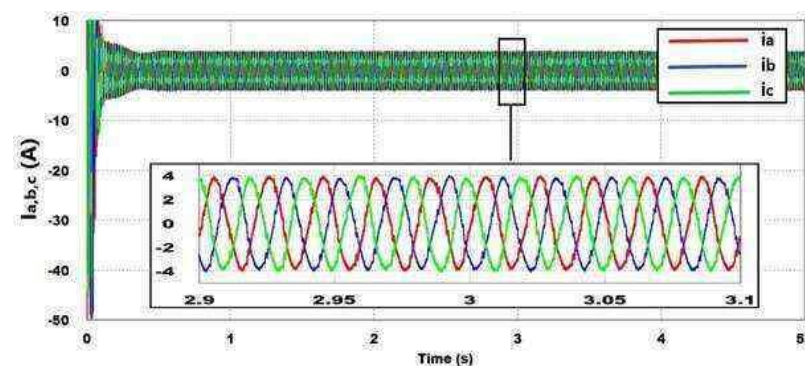

(b)

Figure 28. Micro-inverter waveforms with output reactive power of- 268Var and phase displacement angle $15^{\circ}$ (a) output phase voltage and output phase current (b) three-phase output currents.

The simulation is discussed in this section to check the feasibility of the proposed control scheme of a three-phase grid-connected microinverter system.

Figure 29, shows the PV current, PV voltage of PV array at -268 Var output reactive power and phase displacement angle $-15^{\circ}$.

Figure 30, shows the DC-Link voltage at 268Var output reactive power and phase displacement angle $-15^{\circ}$. Figure 31, shows $\mathrm{I}_{\mathrm{d}}=3.66 \mathrm{~A}$ and $\mathrm{I}_{\mathrm{q}}=-0.994 \mathrm{~A}$ at -268 Var output reactive power and phase displacement angle $15^{\circ}$.

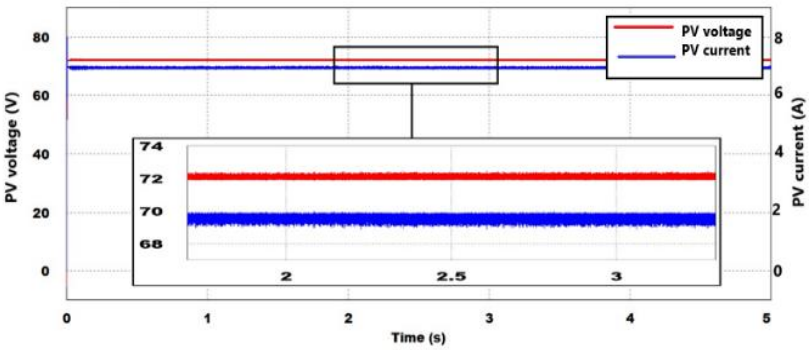

Figure 29. PV current and PV voltage at -268Var output reactive power and phase displacement angle $-15^{\circ}$.

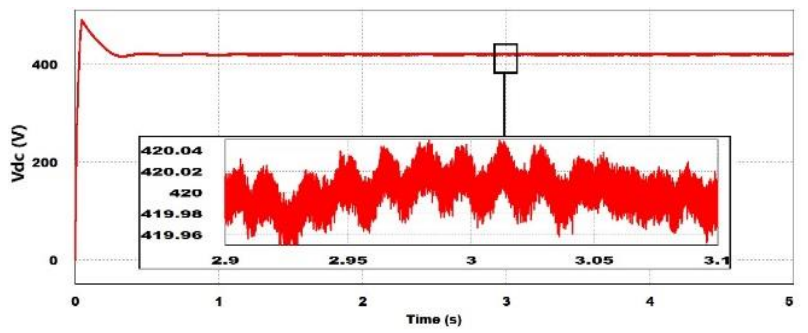

Figure 30. DC-link voltage at -268 Var output reactive power and phase displacement angle $-15^{\circ}$.

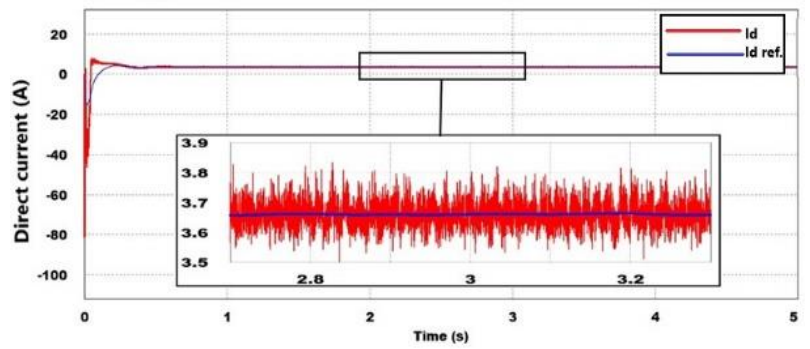

(a)

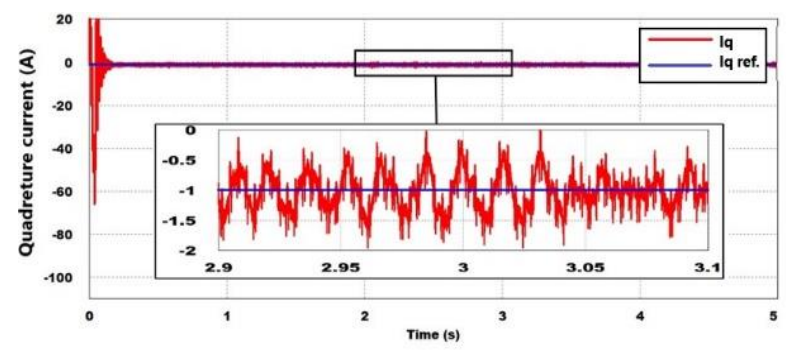

(b)

Figure 31. (a) $I_{d}$ and reference $I_{d}$ at -268Var output reactive power and phase displacement angle $-15^{\circ}$ (b) $I_{q}$ and reference of $I_{q}$ at -268 Var output reactive power and phase displacement angle $-15^{\circ}$.

\subsection{System performance through a change of irradiation}

Figure 32, represents the micro-inverter operation with a change of power form [1000W to $910.8 \mathrm{~W}$ to $617 \mathrm{~W}$ to $815.5 \mathrm{~W}$ to $514.3 \mathrm{~W}$ ] 
depending on the change in PV panel irradiation from $\left[1000 \mathrm{~W} / \mathrm{m}^{2}\right.$ to $900 \mathrm{~W} / \mathrm{m}^{2}$ to $600 \mathrm{~W} / \mathrm{m}^{2}$ to $800 \mathrm{~W} / \mathrm{m}^{2}$ to $500 \mathrm{~W} / \mathrm{m}^{2}$ ]. The waveforms appear in figure 32 (a) \& (b) include PV irradiation and output active power respectively.

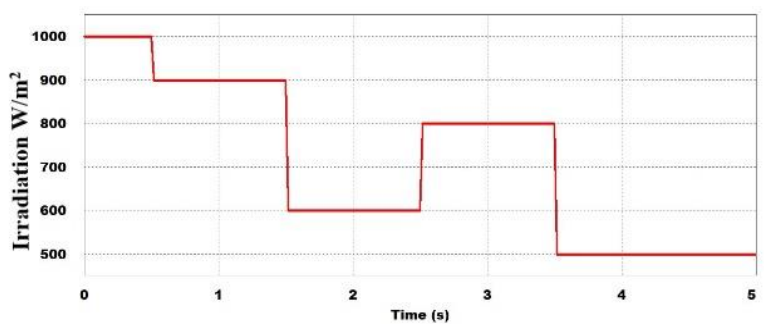

(a)

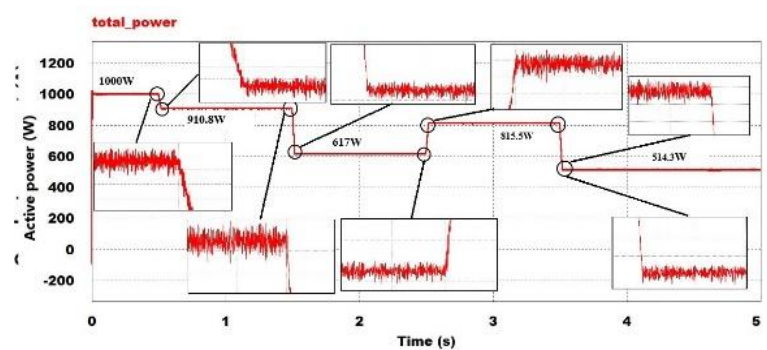

(b)

Figure 32. (a) Solar cells irradiation change from 1000 $\mathrm{W} / \mathrm{m}^{2}$ to $900 \mathrm{~W} / \mathrm{m}^{2}$ to $600 \mathrm{~W} / \mathrm{m}^{2}$ to $800 \mathrm{~W} / \mathrm{m}^{2}$ to 500 $\mathrm{W} / \mathrm{m}^{2}$ (b) Active power through irradiation change.

Figure 33 (a), shows the dynamic response of irradiation change from $1000 \mathrm{~W} / \mathrm{m}^{2}$ to 750 $\mathrm{W} / \mathrm{m}^{2}$ through system operation and no reactive power and Figure 33 (b), shows three-phase output currents through the change.

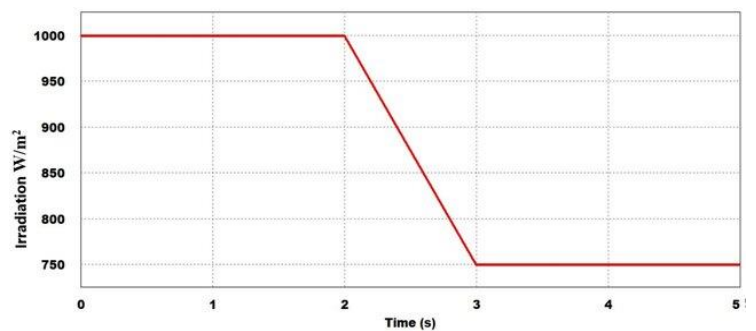

(a)

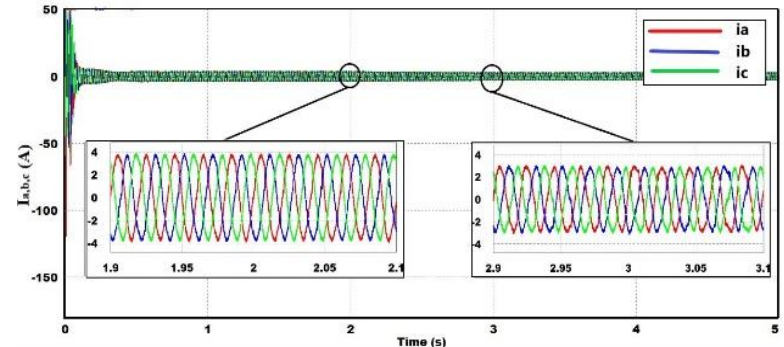

(b)

Figure 33. (a) Solar cells irradiation change from 1000 $\mathrm{W} / \mathrm{m}^{2}$ to $750 \mathrm{~W} / \mathrm{m}^{2}$ (b) three-phase output currents.

Figure 34, shows the PV array voltage is constant through irradiation change from 1000 $\mathrm{W} / \mathrm{m}^{2}$ to $750 \mathrm{~W} / \mathrm{m}^{2}$ and no reactive power. Figure 35, shows the PV array current is reduced through irradiation change from 1000 $\mathrm{W} / \mathrm{m}^{2}$ to $750 \mathrm{~W} / \mathrm{m}^{2}$. Figure 36 shows the boost inductor current through irradiation change from $1000 \mathrm{~W} / \mathrm{m}^{2}$ to $750 \mathrm{~W} / \mathrm{m}^{2}$. Figure 37 , shows $\mathrm{I}_{\mathrm{d}}$ and $\mathrm{I}_{\mathrm{q}}$ currents through irradiation change from $1000 \mathrm{~W} / \mathrm{m}^{2}$ to $750 \mathrm{~W} / \mathrm{m}^{2}$.

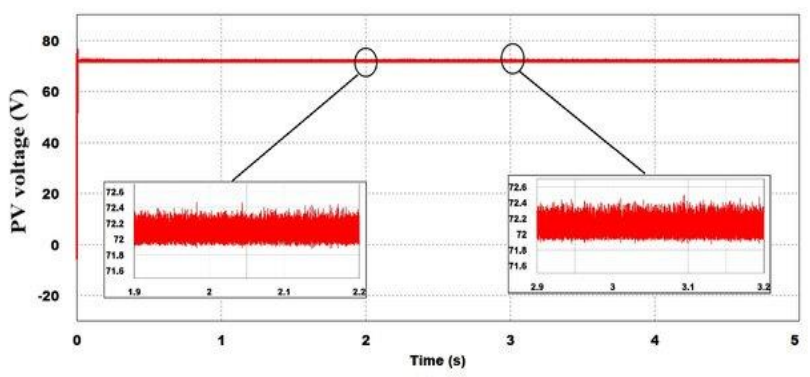

Figure 34. The PV array voltage through irradiation change from $1000 \mathrm{~W} / \mathrm{m}^{2}$ to $750 \mathrm{~W} / \mathrm{m}^{2}$.

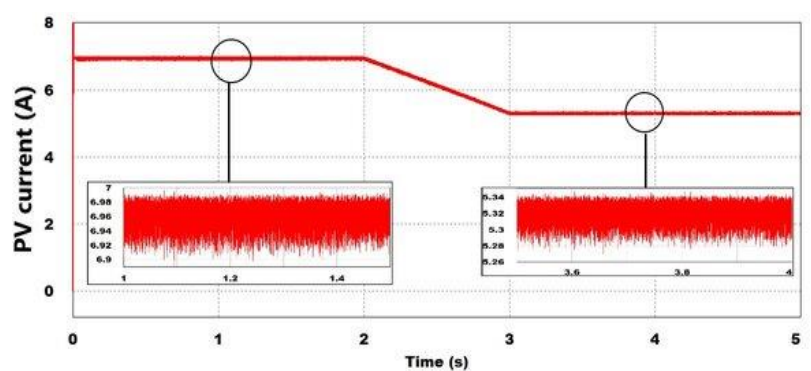

Figure 35. The PV array current through irradiation change from $1000 \mathrm{~W} / \mathrm{m}^{2}$ to $750 \mathrm{~W} / \mathrm{m}^{2}$ 


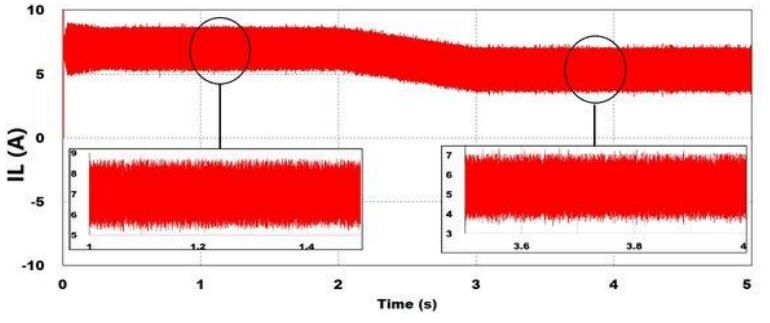

Figure 36. The boost inductor current through irradiation change from $1000 \mathrm{~W} / \mathrm{m}^{2}$ to $750 \mathrm{~W} / \mathrm{m}^{2}$.

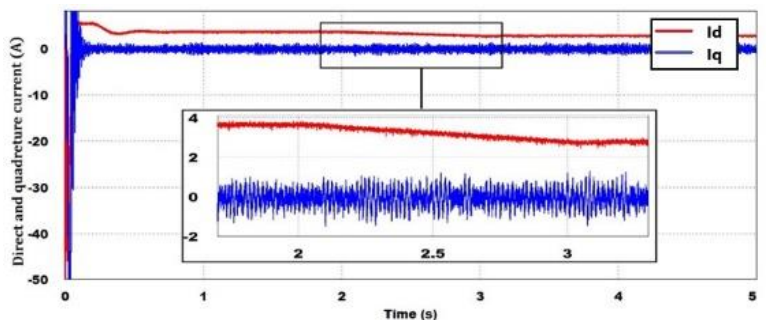

Figure 37. $I_{d}$ and $I_{q}$ through irradiation change from 1000 $\mathrm{W} / \mathrm{m}^{2}$ to $750 \mathrm{~W} / \mathrm{m}^{2}$.

Figure 38 (a), shows the dynamic response of reactive power when a change from 0Var to 268Var to 577 Var and active power at full power rated and obtained that the current is change in phase shift according to the change in reactive power value as shown in figure 38 (b) shows the three-phase output currents through this change.

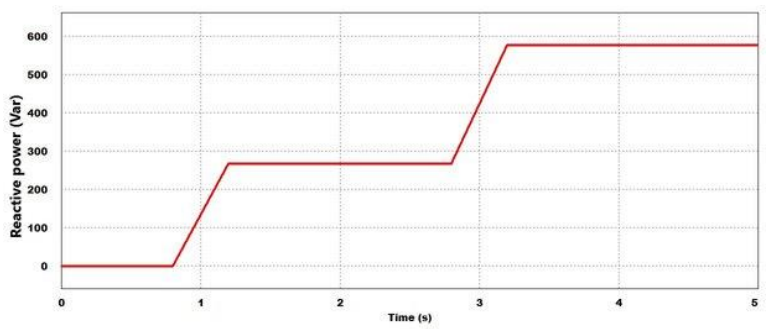

(a)

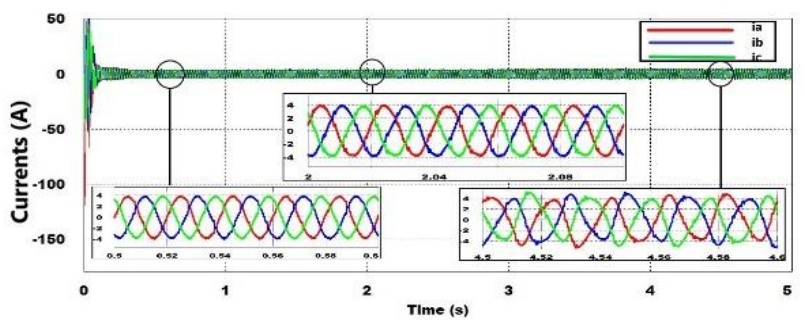

(b)

Figure 38. (a) Dynamic response of reactive power when a change from 0Var to 268Var to 577 Var (b) Three-phase output currents through dynamic response of reactive power.

\section{Conclusion}

In this paper, the design of reactive power control of a three-phase micro-inverter is described. The converter is composed of the interleaved DC-DC booster, a VSI is used as an integrated micro-inverter with a sinusoidal PWM strategy. Proper control of the associated boost converter such as DC voltage regulator and current controller allows DC-DC boost converter and MPPT for each of the PV panels.

The results using the MATLAB Simulink environment show the validity of the PV microinverter system and the good dynamic performance of all controlled variables. The micro inverter is suitable for applications for AC PV module with reactive power control ranges and sinusoidal three-phase balanced output currents, irrespective to partial shading of PV panels. The results obtained that the output power of the PV panel depends on the change in irradiation and other environmental conditions on the PV system. The micro-inverter that is designed at $1000 \mathrm{~W}$ can inject active and reactive power into the grid of $110 \mathrm{~V}$ by controlling direct and quadrature current components.

\section{Acknowledgements}

The authors express their thanks to related supports and relevant staffs have given that financial support or academic information to his or her research.

\section{Conflict of interest}

The authors confirm that the publication of this research causes no conflict of interest.

\section{References}

1. T. Kurbatova and T. Perederii, "Global trends in renewable energy development," 2020 IEEE KhPI Week Adv. Technol. KhPI Week 2020 - Conf. Proc., pp. 260 263, 2020 ,

doi: 
10.1109/KhPIWeek51551.2020.9250098

2. E. Kabalci, G. Gokkus, and A. Gorgun, "Design and implementation of a PIMPPT based Buck-Boost converter," in 2015 7th International Conference on Electronics, Computers and Artificial Intelligence (ECAI), 2015, p. SG-23.

3. I. O. Klopov, Global Trends in Renewable Energy, vol. 1, no. 40. 2015.

4. E. Bielskis, A. Baskys, and G. Valiulis, "Controller for the grid-connected microinverter output current tracking," Symmetry (Basel)., vol. 12, no. 1, p. 112, 2020.

5. D. Pilakkat and S. Kanthalakshmi, "An improved $P \& O$ algorithm integrated with artificial bee colony for photovoltaic systems under partial shading conditions," Sol. Energy, vol. 178, no. March 2018, pp. 37-47, 2019, doi: 10.1016/j.solener.2018.12.008.

6. C. Rodriguez and G. A. J. Amaratunga, "Long-lifetime power inverter for photovoltaic AC modules," IEEE Trans. Ind. Electron., vol. 55, no. 7, pp. 25932601, 2008.

7. R. Tonkoski and L. A. C. Lopes, "Impact of active power curtailment on overvoltage prevention and energy production of $P V$ inverters connected to low voltage residential feeders," Renew. Energy, vol. 36, no. 12, pp. 3566-3574, 2011.

8. L. Collins and J. K. Ward, "Real and reactive power control of distributed $P V$ inverters for overvoltage prevention and increased renewable generation hosting capacity," Renew. Energy, vol. 81, pp. 464-471, 2015.

9. M. A. Ghasemi and M. Parniani, "Prevention of distribution network overvoltage by adaptive droop-based active and reactive power control of $P V$ systems," Electr. Power Syst. Res., vol. 133, pp. 313-327, 2016.

10. G. M. T. Nguyen and K. Uchida, "Active and reactive power control techniques based on feedback linearization and fuzzy logic for three-phase grid-connected photovoltaic inverters," Asian J. Control, vol. 17, no. 5, pp. 1522-1546, 2015.
11. C. T. Rodríguez, D. V. De La Fuente, G. Garcerá, E. Figueres, and J. A. G. Moreno, "Reconfigurable control scheme for a PV microinverter working in both gridconnected and island modes," IEEE Trans. Ind. Electron., vol. 60, no. 4, pp. 15821595, 2011.

12. T. Fawzy, D. Premm, B. Bletterie, and A. Goršek, "Active contribution of $P V$ inverters to voltage control-from a smart grid vision to full-scale implementation," $e$ $i$ Elektrotechnik und Informationstechnik, vol. 128, no. 4, pp. 110-115, 2011.

13. A. M. Howlader, S. Sadoyama, L. R. Roose, and S. Sepasi, "Distributed voltage regulation using Volt-Var controls of a smart PV inverter in a smart grid: An experimental study," Renew. Energy, vol. 127, pp. 145-157, 2018.

14. M. Kolhe and M. Rasul, "3-Phase gridconnected building integrated photovoltaic system with reactive power control capability," Renew. Energy, 2020.

15. K. Kumar, S. R. Kiran, T. Ramji, S. Saravanan, P. Pandiyan, and N. Prabaharan, "Performance Evaluation of PhotoVoltaic System with Quadratic Boost Converter Employing with MPPT Control Algorithms" Int. J. Renew. Energy Res., vol. 10, no. 1, 2020.

16. M. S. Simoiu, V. Calofir, S. S. Iliescu, I. Fagarasan, and N. Arghira, "BOOST converter modelling as a subsystem of a photovoltaic panel control system," in 2020 IEEE International Conference on Automation, Quality and Testing, Robotics (AQTR), 2020, pp. 1-6.

17. N. Parveen and K. C. Rupesh, "Design and simulation of interleaved $D C-D C$ boost converter for three-phase loads using solar panel," in 2016 International Conference on Computation of Power, Energy Information and Commuincation (ICCPEIC), 2016, pp. 514-519.

18. W. Xiao and W. G. Dunford, "A modified adaptive hill climbing MPPT method for photovoltaic power systems," in 2004 IEEE 35th annual power electronics specialists conference (IEEE Cat. No. 04CH37551), 2004, vol. 3, pp. 1957-1963. 
19. M. L. Azad, S. Das, P. Kumar Sadhu, B. Satpati, A. Gupta, and P. Arvind, " $P \& O$ algorithm based MPPT technique for solar $P V$ system under different weather conditions," Proc. IEEE Int. Conf. Circuit, Power Comput. Technol. ICCPCT 2017, pp. $\quad$ 0-4, 2017, doi: 10.1109/ICCPCT.2017.8074225.

20. R. Benadli, B. Khiari, and A. Sellami, "Three-phase grid-connected photovoltaic system with maximum power point tracking technique based on voltageoriented control and using sliding mode controller," in IREC2015 The Sixth International Renewable Energy Congress, 2015, pp. 1-6.

21. Z. Layate, T. Bahi, I. Abadlia, H. Bouzeria, and S. Lekhchine, "ScienceDirect Reactive power compensation control for three phase gridconnected photovoltaic generator," Int. J. Hydrogen Energy, pp. 1-8, 2015, doi: 10.1016/j.ijhydene.2015.07.087. 